\title{
Community structure of marine sedimentary protists in relation to flow and grain size
}

\author{
Jeff Shimeta ${ }^{1,4, *}$, Rebecca J. Gast ${ }^{2}$, Julie M. Rose $^{3}$ \\ ${ }^{1}$ Biology Department, Franklin \& Marshall College, Lancaster, Pennsylvania 17604-3003, USA \\ ${ }^{2}$ Biology Department, Woods Hole Oceanographic Institution, Woods Hole, Massachusetts 02543, USA \\ ${ }^{3}$ College of Marine and Earth Studies, University of Delaware, Lewes, Delaware 19958, USA \\ ${ }^{4}$ Present address: Department of Zoology, University of Melbourne, Parkville, Victoria 3010, Australia
}

\begin{abstract}
Populations of unicellular, marine sedimentary protists are constrained by a variety of physical environmental factors, but influences of flow regime have rarely been studied. We compared community structure among 3 subtidal sites differing in flow strength and grain size in a coastal bay. We used denaturing gradient gel electrophoresis (DGGE) to assess eukaryotic diversity based on 18S rDNA, and quantitative Protargol staining (QPS) to examine ciliate communities by microscopy. Sedimentary $18 \mathrm{~S}$ rDNA in mid-summer was dominated by diatoms. Analyses of gel bands by presence/ absence among sites, dendogram, and multidimensional scaling showed that eukaryotic community structure was related to grain size more strongly than to flow regime. Among bands identified as diatoms by recovery and sequence analysis, 4 taxa $(40 \%)$ differed among sites in relation to flow strength, and 2 taxa (29\%) differed in relation to grain size. No bands had sequences matching ciliates, but QPS showed that 6 ciliate species $(20 \%)$ were distributed in relation to flow, and 10 species $(33 \%)$, in relation to grain size. Ciliate species richness and community similarity were greatest for the 2 strong-flow sites, despite differences in mean grain size. The strong-flow, silty site had the highest concentrations of chlorophyll $a$, total ciliates, karyorelictids, and scuticociliates, and the lowest ciliate species diversity. DGGE was run again for this site 1 mo later and revealed a shift in the rDNA pool to dominance by metazoans. Flow regime and grain size may be important factors structuring subtidal communities of sedimentary protists.
\end{abstract}

KEY WORDS: Ciliates $\cdot$ Diatoms $\cdot$ Benthic $\cdot$ Community structure $\cdot$ Flow $\cdot$ Grain size $\cdot$ DGGE

\section{INTRODUCTION}

Unicellular sedimentary protists play important roles in shallow marine ecosystems. Microphytobenthos can be a significant or dominant component of total primary production, and they support benthic secondary production (MacIntyre et al. 1996, Miller et al. 1996). Heterotrophic protists consume bacterial and microalgal production, they facilitate remineralization of detritus deposited from the water column, and they are consumed by meiofauna and macrofauna (Patterson et al. 1989, Epstein 1997a,b). When resuspended, sedimentary protists contribute to benthic-pelagic coupling, altering water-column biomass and community structure, contributing to water-column production and serving as food for zooplankton and benthic suspension feeders (Shaffer \& Sullivan 1988, de Jonge \& van Beusekom 1992).

Despite the clear ecological importance of unicellular sedimentary protists, an understanding of fundamental aspects of their ecology such as factors determining distributions and abundances, species structure of communities, and activities is far from complete. The most apparent influences on unicellular sedimentary protists are those of physical factors such as temperature, salinity, light penetration, dissolved oxygen, redox potential, nutrients, and grain size (Patterson et al. 1989, MacIntyre et al. 1996, Cahoon et al. 
1999, Fernandez-Leborans 2001). Most of this research has been done in intertidal habitats, whereas little work has addressed the physical factors influencing subtidal populations.

Recent studies have revealed impacts of flow regime on benthic protozoa and microalgae. Flow strength affects feeding rates of subtidal ciliates (Shimeta et al. 2001) and the species structure of ciliate communities on sandy shores (Lucchesi \& Santangelo 1997). Resuspension stimulates growth and trophic interactions of unicellular sedimentary protists (Garstecki \& Wickham 2001, Garstecki et al. 2002), and the fact that benthic diatoms and ciliates each show species-specific resuspension dynamics (Lucas et al. 2001, Shimeta et al. 2002 , 2003) also suggests that flow regime can influence populations differentially and possibly impact community structure. Furthermore, resuspension dynamics can differ between sites in ways suggesting an interaction between flow regime and grain size (Shimeta et al. 2003). Detailed analyses of community structure have not been conducted, however, in relation to flow regime at subtidal habitats.

Here we assess community structure at subtidal sites (ca. $15 \mathrm{~m}$ depth) that differ in flow regime and grain size in a coastal embayment, Buzzards Bay, Massachusetts, USA. These factors vary in a complex fashion throughout the bay, with the current speed changing along the long axis of the bay and the grain size changing across the bay, thus creating varied combinations of flow and sediment characteristics (Moore 1963). We sampled at 3 nearby sites of similar depth; 2 of these had similar flow strengths and 2 others had similar grain sizes. This design allowed comparisons between sites that differ in flow strength, but not grain size, and between sites that differ in grain size, but not flow strength.

For a broad assessment of protistan diversity, we used denaturing gradient gel electrophoresis (DGGE) to separate fragments of the 18S rRNA gene that we extracted from the sediment and amplified by polymerase chain reaction (PCR) using eukaryotic primers. DGGE allows rapid assessment of protistan diversity and its variation among samples (van Hannen et al. 1998, Gast et al. 2004, Countway et al. 2005). The method has been extensively applied to prokaryotic analyses in sediments (e.g. Piceno et al. 1999, Webster et al. 2003), but has rarely been used to assess protistan diversity in such samples (Coyne et al. 2001). Because of our particular interest in the ciliate communities, and the fact that molecular assessments of community structure can disagree with morphological assessments due to extraction and PCR biases (Savin et al. 2004, Cook et al. 2005), we also examined ciliates microscopically using quantitative Protargol staining (QPS; Montagnes \& Lynn 1987).

\section{MATERIALS AND METHODS}

Field sites and sample collection. Samples were collected at the following unvegetated, subtidal stations in Buzzards Bay, Massachusetts, USA (Fig. 1):

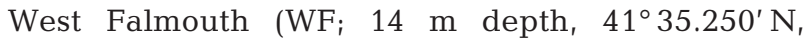
$\left.70^{\circ} 42.750^{\prime} \mathrm{W}\right)$; Round Hill $\left(\mathrm{RH}_{i} 15 \mathrm{~m}\right.$ depth, $41^{\circ} 31.959^{\prime} \mathrm{N}, 70^{\circ} 54.171^{\prime} \mathrm{W}$ ), and Weepecket Island (WI; $15.5 \mathrm{~m}$ depth, $41^{\circ} 31.250^{\prime} \mathrm{N}, 70^{\circ} 45.700^{\prime} \mathrm{W}$ ). WF and WI are $8.5 \mathrm{~km}$ apart, and they are, respectively, 11.9 and $17.0 \mathrm{~km}$ from $\mathrm{RH}$.

Flow was measured $1.2 \mathrm{~m}$ above bottom at each station using an InterOcean S4 current meter mounted on a bottom tripod. Flow speed was converted to friction velocity, which is a measure of shear stress on the bed, and it reflects the level of turbulence and steepness of the velocity gradient experienced by organisms at the sediment-water interface (Nowell \& Jumars 1984). Friction velocity $\left(u_{*}\right)$ was estimated as: $u_{*}=\left(C_{\mathrm{D}}\right)^{1 / 2} u_{\text {, }}$ where $u$ is speed and $C_{\mathrm{D}}$ is a drag coefficient. Sternberg's (1968) mean $C_{\mathrm{D}}=3.1 \times 10^{-3}$ for $1 \mathrm{~m}$ above bottom (m.a.b.) in coastal waters was adjusted using the

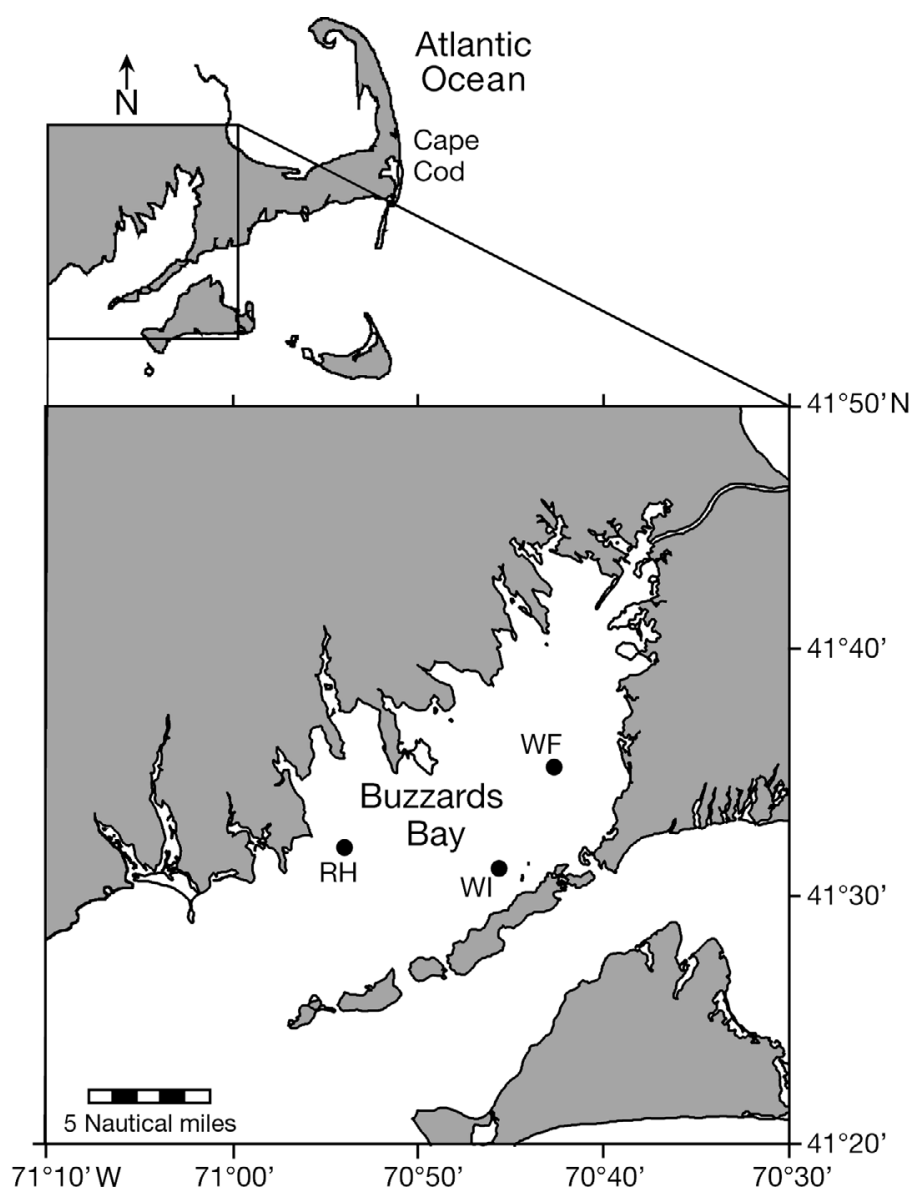

Fig. 1. Sampling stations in Buzzards Bay, North Atlantic coast, USA. Station letters refer to nearby landmarks - WF: West Falmouth; RH: Round Hill; WI: Weepecket Island 
Law of the Wall (Middleton \& Southard 1984) to $2.98 \times$ $10^{-3}$ for a height of 1.2 m.a.b. Use of the Law of the Wall and a drag coefficient in estimating friction velocity from speed at a single height is justified because logarithmic boundary-layer velocity profiles were confirmed by measurements with an Acoustic Doppler Current Profiler (Shimeta \& Sisson 1999, Shimeta et al. 2002), and the unvegetated sediments at these sites are spatially uniform and lack flow obstacles.

Sediment cores were collected by SCUBA divers. Except as noted below, replicate samples were from separate cores collected on the same dive within several meters of one another, and samples were processed immediately. Cores of $3.8 \mathrm{~cm}$ diameter were used to determine grain-size distributions in the top $2 \mathrm{~mm}$ by mass fractions after wet sieving (Shimeta et al. 2003). On 12 July 2004, cores of $2.6 \mathrm{~cm}$ diameter were collected from all 3 stations, and the top $4 \mathrm{~mm}$ of sediment was used for the following analyses. Particulate organic matter was measured as the difference in dry weight before and after ashing at $450^{\circ} \mathrm{C}$ for $5 \mathrm{~h}$, corrected for salt content. Chlorophyll a was measured on a Turner Designs fluorometer after extraction in $90 \%$ acetone (Parsons et al. 1984). Samples for enumerating bacteria and protists by microscopy (including QPS) were preserved with ice-cold $1 \%$ final glutaraldehyde, whereas samples for DGGE were unpreserved. On 13 August 2004, cores of $10.8 \mathrm{~cm}$ diameter were collected at Station WI for DGGE only. On this date, replicate subsamples of the top $3 \mathrm{~mm}$ of sediment were taken from several locations within a single core, and the samples were frozen prior to DNA extraction.

Nucleic acid extraction from sediment and single ciliate cells. Nucleic acids were extracted from approximately $1 \mathrm{~g}$ of each sediment sample using the MoBio PowerSoil DNA Kit following the manufacturer's instructions. July sediments were extracted immediately after collection, whereas the August samples were frozen for approximately 1 mo before being extracted. Then, $1 \mu$ l of the recovered DNA was used directly in DGGE PCR amplifications.

Individual ciliate cells were isolated from sediments using pulled glass capillary micropipettes. Each cell was washed twice in filter-sterilized seawater $(0.2 \mu \mathrm{m})$, then placed into individual sterile $0.2 \mathrm{ml}$ centrifuge tubes with $<5 \mu$ l of water. Cells were lysed using $5 \mu$ l of the Lyse-N-Go PCR reagent and the thermal cycle program given in the reagent protocol. After completion of the lysis cycle, $95 \mu \mathrm{l}$ of PCR reagents were added to each tube. The reagents included $0.25 \mu \mathrm{l}$ Taq polymerase, $1 \times$ reaction buffer, $2.5 \mathrm{mM} \mathrm{MgCl}_{2}$, $0.25 \mathrm{mM}$ of each nucleotide, and $200 \mathrm{ng}$ of each eukaryotic small subunit ribosomal gene primer (A and B; Medlin et al. 1988).
PCR amplification. Amplification of the 18S rDNA from single ciliate cells was accomplished using a nested PCR approach. The first amplification used eukaryote-specific $18 \mathrm{~S}$ rDNA primers that targeted the full-length gene (A and B; Medlin et al. 1988), while the second and third amplifications used primer combinations that were directed to internal regions of the gene (373 and B, second round, Weekers et al. 1994; 960GC and 1200R, third round, Gast et al. 2004). Then, $10 \mu \mathrm{l}$ of each previous amplification reaction was used as the template for the following reaction, and the total reaction volume was $100 \mu$ l. The thermal cycle used for the first and second rounds of amplification was $94^{\circ} \mathrm{C}$ for $3 \mathrm{~min}$, followed by 30 cycles of $94^{\circ} \mathrm{C}$ for $45 \mathrm{~s}, 55^{\circ} \mathrm{C}$ for $45 \mathrm{~s}$, and $72^{\circ} \mathrm{C}$ for $3 \mathrm{~min}$; and a final extension of $72^{\circ} \mathrm{C}$ for $5 \mathrm{~min}$. The final single-cell amplification, and the sediment amplification, used the DGGE primer set and the DGGE touchdown amplification process described in Gast et al. (2004). The size of the DGGE PCR product was approximately $250 \mathrm{bp}$.

DGGE analysis. PCR products were precipitated using a final concentration of $0.3 \mathrm{M}$ sodium acetate and 0.6 vol of $100 \%$ isopropanol. The mixtures were allowed to precipitate overnight at $-20^{\circ} \mathrm{C}$, then centrifuged at maximum speed (usually 15000 to $20000 \times g$ ) in a microcentrifuge for $10 \mathrm{~min}$. The liquid was removed, and the pellet allowed to air-dry. Products were resuspended in $5 \mu \mathrm{l}$ of sterile distilled water, and, prior to loading on the DGGE gel, $5 \mu \mathrm{l}$ of non-denaturing loading buffer $(40 \%$ Ficoll 400 , 10 mM Tris, pH 7.8, 1 mM EDTA, $0.1 \%$ bromphenol blue) was added.

DGGE analysis was performed on a CBS Scientific Model DGGE-2000 gel apparatus, as described in Gast et al. (2004). PCR products were not quantified, but, after an initial gel run using $3 \mu$ of sample, a second gel was run with the amount loaded adjusted to give relatively similar band intensities between samples. Briefly, 3 to $6 \mu$ l of resuspended product was loaded into each well of an $8 \%$ polyacrylamide gel that contained an increasing denaturing gradient (35 to 85\%; $2.5 \mathrm{M}$ urea, $14 \%$ formamide to $6 \mathrm{M}$ urea, $34 \%$ formamide). The gel was run overnight at $60^{\circ} \mathrm{C}$ and $95 \mathrm{~V}$. After completion of the run, the gel was stained with ethidium bromide, visualized, and digitally photodocumented. The digital image was analyzed using GelComparII (Applied Maths) with manual confirmation of band calling. Cluster analysis was run using a band tolerance of $0.5 \%$, the Dice coefficient, and unweighted pair-group method using arithmetic averages (UPGMA). Consistency of the clusters was examined using cophenetic variation. Cophenetic variation is a parameter used by the GelComparII program to express the faithfulness of a cluster on the dendogram. It calculates the correlation between the dendogram- 
derived similarities (cluster results) and the matrixderived similarities (data matrix generated from band presence/absence results).

A matrix of band presence/absence generated from the DGGE gel (July samples only) was statistically analyzed using the multivariate statistical program Primer v6 (Clarke \& Gorley 2006). Three analysis of similarity (ANOSIM) tests were performed on the presence/ absence data. Samples grouped according to location, mean friction velocity, or mean grain size were examined for significant differences in community structure. The RH and WF sites were grouped together in the ANOSIM test of mean grain size (sandy), and this group was compared to the samples taken at Site WI (silty). The RH and WI sites were grouped together in the ANOSIM test of mean friction velocity (strong flow), and this group was compared to the samples taken at Site WF (weak flow). Data from August samples were not included in the ANOSIM test because it was meant to test for the effects of flow strength and grain size, not time.

Sequencing. Individual bands were recovered from the DGGE gel using plugged micropipette tips. The desired band was touched with the micropipette tip, and then the tip was rinsed several times in $6 \mu \mathrm{l}$ of sterile distilled PCR water. We have found this method of band recovery to work reliably and to reduce the recovery of multiple bands. Two microliters of the recovered band product were reamplified with nonGC-clamped 960F and 1200R primers. These products were isopropanol-precipitated, as described previously, and then resuspended in $5 \mu$ l of sterile distilled water. Then, 1 to $2 \mu$ l of product was sequenced directly using the ABI Prism Big Dye Terminator Cycle Sequencing Ready Reaction Kit and the $960 \mathrm{~F}$ or $1200 \mathrm{R}$ primers. Sequencing reactions were run on an ABI 377 (Applied Biosystems) and analyzed using Sequencher 4.1 (Gene Codes Corporation). BLAST (Altschul et al. 1997) searches were performed to determine taxonomic affinities of the sequences.

Microscopical analyses of cells. Bacteria were separated from sediment by sonication, and protists were extracted by Percoll-gradient centrifugation, after which cells were stained with DAPI, and the bacteria and nanoflagellates were counted using epifluorescence microscopy (Shimeta \& Sisson 1999, Shimeta et al. 2003). Nanoflagellates were classified as pigmented if chlorophyll fluorescence was visible under blue excitation. To identify and count ciliates, extracted cells were post-fixed in Bouin's fixative and stained following the QPS method (Montagnes \& Lynn 1987). Ciliates were examined under transmitted light at $1000 \times$ and identified using the keys in Carey (1992) and Lee et al. (2000). The classification of Lee et al. (2000) is followed here.
The Shannon-Wiener index of diversity was calculated for the ciliate community at each station as:

$$
H^{\prime}=-\Sigma p_{i} \ln p_{i}
$$

where $p_{i}$ is the proportion of individuals of species $i$ among the total number of individuals counted in the community sample, and the summation is performed over all species in the sample (Magurran 1988). This index assumes that all species in the community are sampled, and its value is relatively sensitive to the number of rare species. Simpson's index of diversity, another common index that is more sensitive to the abundances of common species (Magurran 1988), was also calculated for comparison. A community-similarity index (CS) was calculated based on Schoener's (1970) measure of species overlap:

$$
\mathrm{CS}=1-0.5 \Sigma\left|p_{i, 1}-p_{i, 2}\right|
$$

where 1 and 2 are the stations being compared, and the summation is as above. One-way ANOVA was performed using Systat v5.2.1 for the Macintosh. When results were significant, Bonferroni-corrected, multiple-comparisons tests were conducted for all pairs of stations.

\section{RESULTS}

\section{Site characteristics}

Near-bottom flow speed displayed strong tidal periodicity at the 3 stations (Fig. 2). Over the course of $4 \mathrm{~d}$ during spring tides with the moon in perigee, $\mathrm{RH}$ and WI had similar flow strengths, both significantly stronger than WF (Table 1). The mean friction velocities at RH $\left(0.72 \mathrm{~cm} \mathrm{~s}^{-1}\right)$ and WI $\left(0.73 \mathrm{~cm} \mathrm{~s}^{-1}\right)$ were 1.8 times greater than that at WF $\left(0.41 \mathrm{~cm} \mathrm{~s}^{-1}\right)$. The peak friction velocities at $\mathrm{RH}\left(1.98 \mathrm{~cm} \mathrm{~s}^{-1}\right)$ and WI $(1.66 \mathrm{~cm}$ $\mathrm{s}^{-1}$ ) were, on average, 2.5 times greater than that at WF $\left(0.72 \mathrm{~cm} \mathrm{~s}^{-1}\right)$.

Table 1. Statistics of flow data in Fig. 2. Mean friction velocity is an average throughout the entire $4 \mathrm{~d}$; peak friction velocity is the maximum value in each tidal cycle; ${ }^{*} \mathrm{p}<0.05$ in ANOVA comparing all stations. For both statistics, Bonferroni-corrected multiple-comparison tests showed that Round Hill (RH) and Weepecket Island (WI) were not significantly different, but each was significantly different from West Falmouth (WF)

\begin{tabular}{|cccc|}
\hline & WF & RH & WI \\
\hline${ }^{*} \begin{array}{l}\text { Mean friction velocity }( \pm \text { SE }) \\
\left(\mathrm{cm} \mathrm{s}^{-1}\right), \mathrm{n}=576\end{array}$ & $\begin{array}{c}0.41 \\
( \pm 0.01)\end{array}$ & $\begin{array}{c}0.72 \\
( \pm 0.02)\end{array}$ & $\begin{array}{c}0.73 \\
( \pm 0.02)\end{array}$ \\
$\begin{array}{l}{ }^{M} \text { Mean peak friction velocity } \\
( \pm \mathrm{SE})\left(\mathrm{cm} \mathrm{s}^{-1}\right), \mathrm{n}=8\end{array}$ & $\begin{array}{c}0.72 \\
( \pm 0.04)\end{array}$ & $\begin{array}{c}1.98 \\
( \pm 0.09)\end{array}$ & $\begin{array}{c}1.66 \\
( \pm 0.13)\end{array}$ \\
\hline
\end{tabular}


A. Station WF

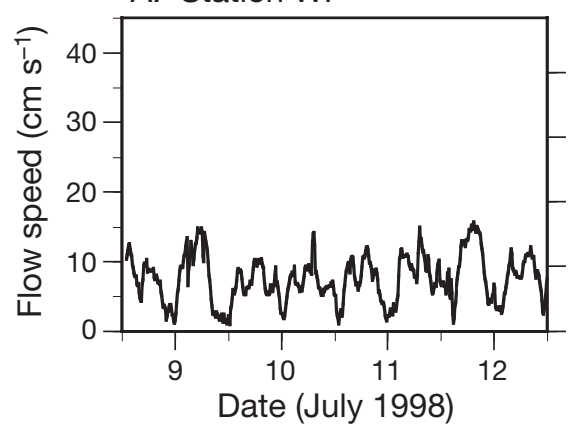

B. Station $\mathrm{RH}$

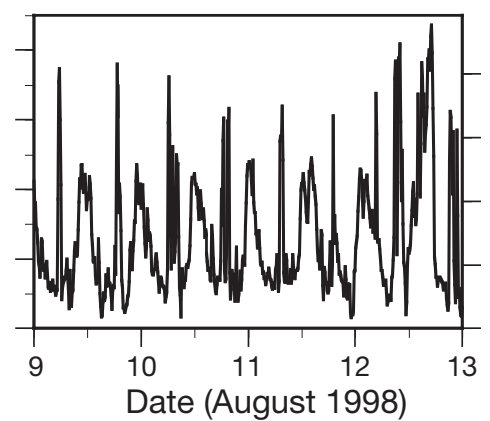

C. Station $\mathrm{Wl}$

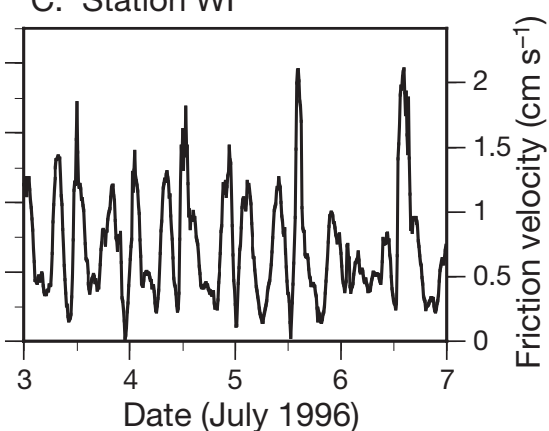

Fig. 2. Near-bottom flow at the 3 stations (WF, RH, WI, see Fig. 1), in each case measured during spring tide when the moon was in perigee. Data were recorded as 10 min averages. Data in (B) and (C) are from Shimeta et al. (2003)

Whereas RH and WI shared similar flow strengths, WF and RH shared similar grain-size distributions (Fig. 3). WF and RH were predominantly fine to coarse sand (>125 $\mu \mathrm{m})$, although they were not well sorted, having small secondary peaks of fine silt-clay (Fig. 3). In contrast, WI was greatly dominated by silt-clay $(80 \%$ of the mass was $<63 \mu \mathrm{m})$. The relations among flow strength and grain size at the 3 sites are illustrated in Fig. 4 .
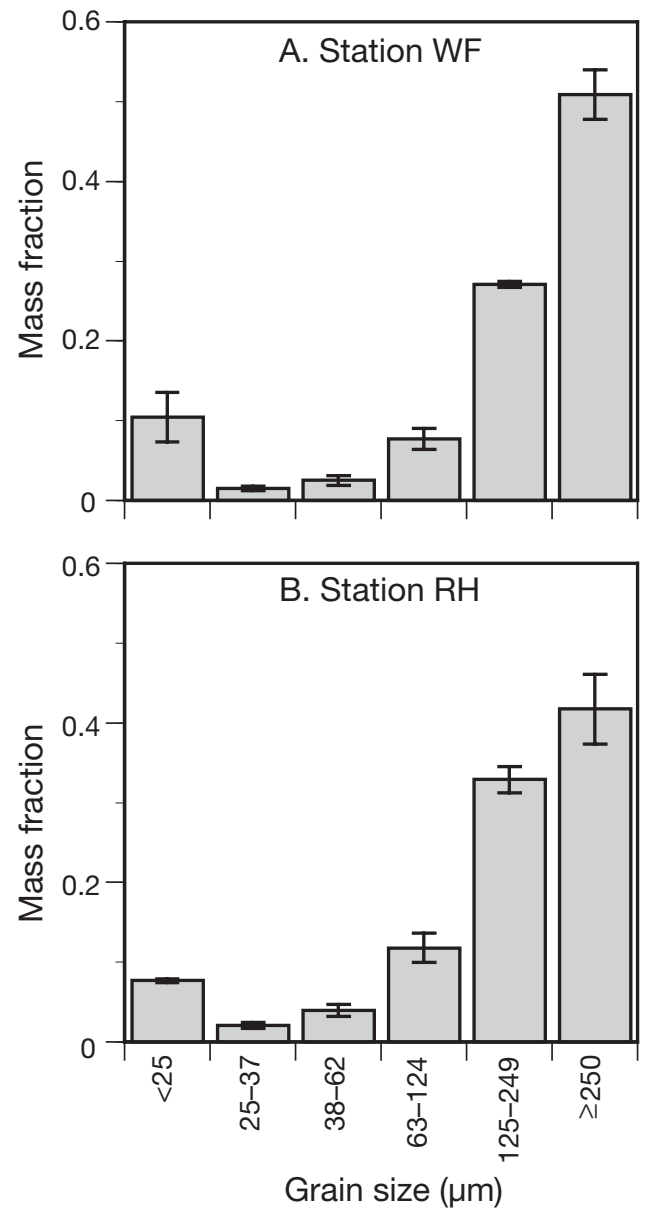

The silty site (WI) had a significantly greater mass fraction of organic matter (by 3.8- to 5.3-fold) than the sandy sites (Table 2). WI also had significantly greater concentrations of chlorophyll a (by 4.8-fold) and ciliates (by 2.7 -fold) than did the sandy sites, which were statistically similar to each other. Concentrations of bacteria, nanoflagellates, and percent pigmented nanoflagellates did not differ significantly among the 3 sites.

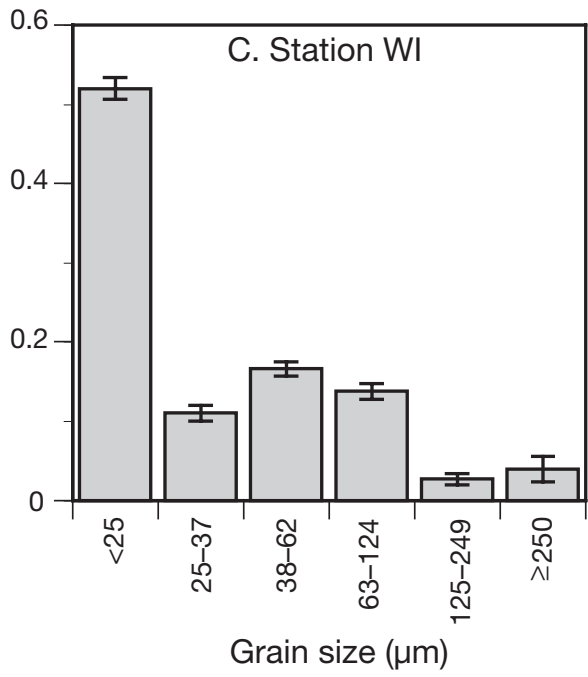

Fig. 3. Grain-size distributions in the top $2 \mathrm{~mm}$ at the 3 stations. Bars show the mean $\pm \mathrm{SE}$ in each size class $(\mathrm{WF}, \mathrm{n}=3$; $\mathrm{RH}, \mathrm{n}=4$; WI, $\mathrm{n}=8$ ). Data in (B) and (C) are from Shimeta et al. (2003). See Fig. 1 for abbreviations 


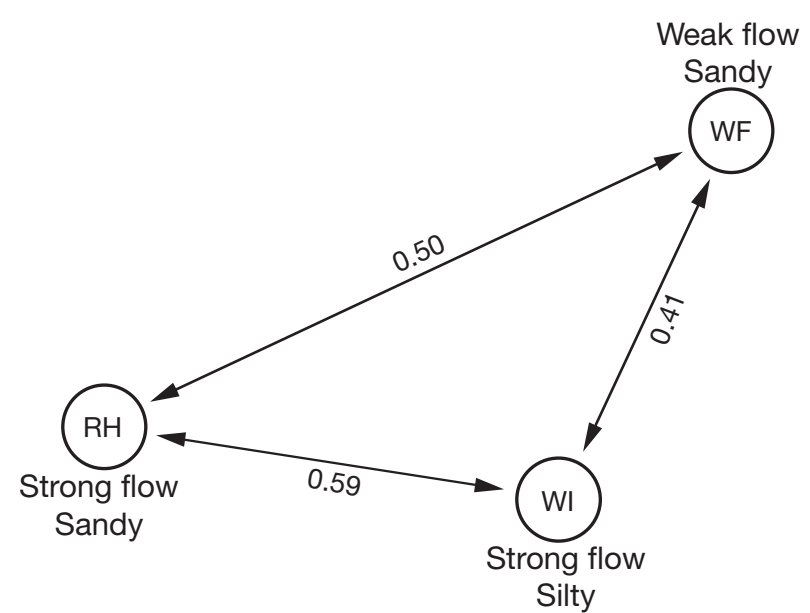

Fig. 4. Flow-regime and grain-size characteristics at the 3 stations, with the index of ciliate community similarity along arrows for pairwise comparisons between stations. See Fig. 1 for abbreviations

\section{DGGE analysis of eukaryotic community structure}

DGGE yielded up to 20 bands in a single sediment sample (Fig. 5, e.g. Lane 7). The presence and density of individual bands differed among the 3 stations, as well as among the replicate samples at each station. We ran replicates in separate lanes to reveal spatial variation at each station, but we consider the bands from all 3 replicates to reflect the total community composition at each station. We retrieved and sequenced rDNA from 30 bands, of which 12 were identified as metazoans, 11 as diatoms, 2 as prymnesiophytes, 1 as a synurophyte, and 4 of uncertain taxonomic affiliation (Fig. 5, Table 3). Primarily, diatom bands were recovered from all of the July samples, whereas the bands from August samples from Station WI were almost entirely metazoan. In several instances, different bands were identified as the same species by BLAST analysis (Table 3). When we directly compared the sequences to each other, they were not identical, and these bands likely represent species or strains. The BLAST matches, however, are limited to the available sequences in the database. Another issue encountered was band similarities $<70 \%$, which was often the result of poor-quality sequences due to ambiguities (Table 3, Bands 8, $9,10,13$, and 32), a fairly common result when sequencing uncloned PCR products. Other low similarities occurred for sequences that were of good quality (Table 3, Bands 30, 31, and 33) and probably resulted from the lack of highly similar sequences in the database. Similarity values $<50 \%$ were considered too low to allow identification. This value reflects the approximate proportion of variable to conserved sites in the DGGE fragment sequence. About $40 \%$ of the sequence is highly variable, so it would be reasonable to expect that any related sequence should have at least $50 \%$ similarity. Lower values likely represent the universally conserved regions of the ribosomal sequence, but cannot be used to establish reasonable taxonomic relationships.

A dendogram (Fig. 6) generated from the DGGE band patterns (including all bands, protistan and metazoan) revealed that the eukaryotic communities at WF and $\mathrm{RH}$ (the sandy sites) were slightly more similar to each other (57\% of bands shared) than they were to the WI community in July (53\% of bands shared). The WI community in August differed from all of the communities in July, sharing only $45 \%$ of the bands.

The global ANOSIM test for differences in eukaryotic community structure among the 3 locations (July samples only) was significant ( $p=0.04, \mathrm{R}=0.79$ ). Individual tests for differences between pairs of locations were not significant ( $p=0.1$ for all 3 pairs). High R-statistics were observed for the pairwise comparisons of WI with either WF $(R=1.000)$ or $R H(R=0.963)$, but the sample size of 3 replicates per site allowed only 10 permutations of the data per comparison, which contributed to the nonsignificant $\mathrm{p}$-values. A lower Rstatistic was observed for the pairwise comparison of the sandy sites (WF and $\mathrm{RH} ; \mathrm{R}=0.574$ ). These trends
Table 2. Parameters measured in sediments collected on 12 July 2004. Cell concentrations are expressed per milliliter of sediment. The first 6 rows are mean values $( \pm \mathrm{SE})$ with $n=4$ for ciliate concentration and $n=3$ for all others. Ciliate richness and diversity were calculated from 4 pooled replicates and thus were not tested statistically. ${ }^{*} \mathrm{p}<0.05$ in ANOVA comparing all stations. Results of Bonferroni-corrected multiple-comparison tests: for chl $a$ and ciliates, WF and $\mathrm{RH}$ were not significantly different, but each was significantly different from WI; for organic matter, all pairwise comparisons were significantly different. See Table 1 for abbreviations

\begin{tabular}{|lccc|}
\hline & WF & RH & WI \\
\hline${ }^{*}$ Organic matter $(\%)$ & $2.8( \pm 0.2)$ & $2.0( \pm 0.03)$ & $10.6( \pm 0.1)$ \\
${ }^{*}$ Chl $a\left(\mathrm{~g} \mathrm{~g}^{-1}\right)$ & $5.2( \pm 0.3)$ & $2.7( \pm 0.2)$ & $18.9( \pm 1.8)$ \\
Bacteria $\left(\right.$ cells ml $\left.{ }^{-1}\right)$ & $1.5( \pm 0.1) \times 10^{9}$ & $1.5( \pm 0.2) \times 10^{9}$ & $1.4( \pm 0.2) \times 10^{9}$ \\
Total nanoflagellates & $5.3( \pm 1.1) \times 10^{5}$ & $5.0( \pm 0.6) \times 10^{5}$ & $6.2( \pm 0.8) \times 10^{5}$ \\
${\left.\text { cells ml }{ }^{-1}\right)}$ & & & \\
Percent pigmented & $28( \pm 4)$ & $21( \pm 9)$ & $31( \pm 4)$ \\
nanoflagellates (\%) & & & $1384( \pm 52)$ \\
${ }^{*}$ Ciliates (cells ml $\left.{ }^{-1}\right)$ & $488( \pm 54)$ & $533( \pm 119)$ & 51 \\
Ciliate richness (no. of species) & 42 & 49 & 2.5 \\
Ciliate species diversity $\left(H^{\prime}\right)$ & 3.1 & 3.0 & \\
\hline
\end{tabular}




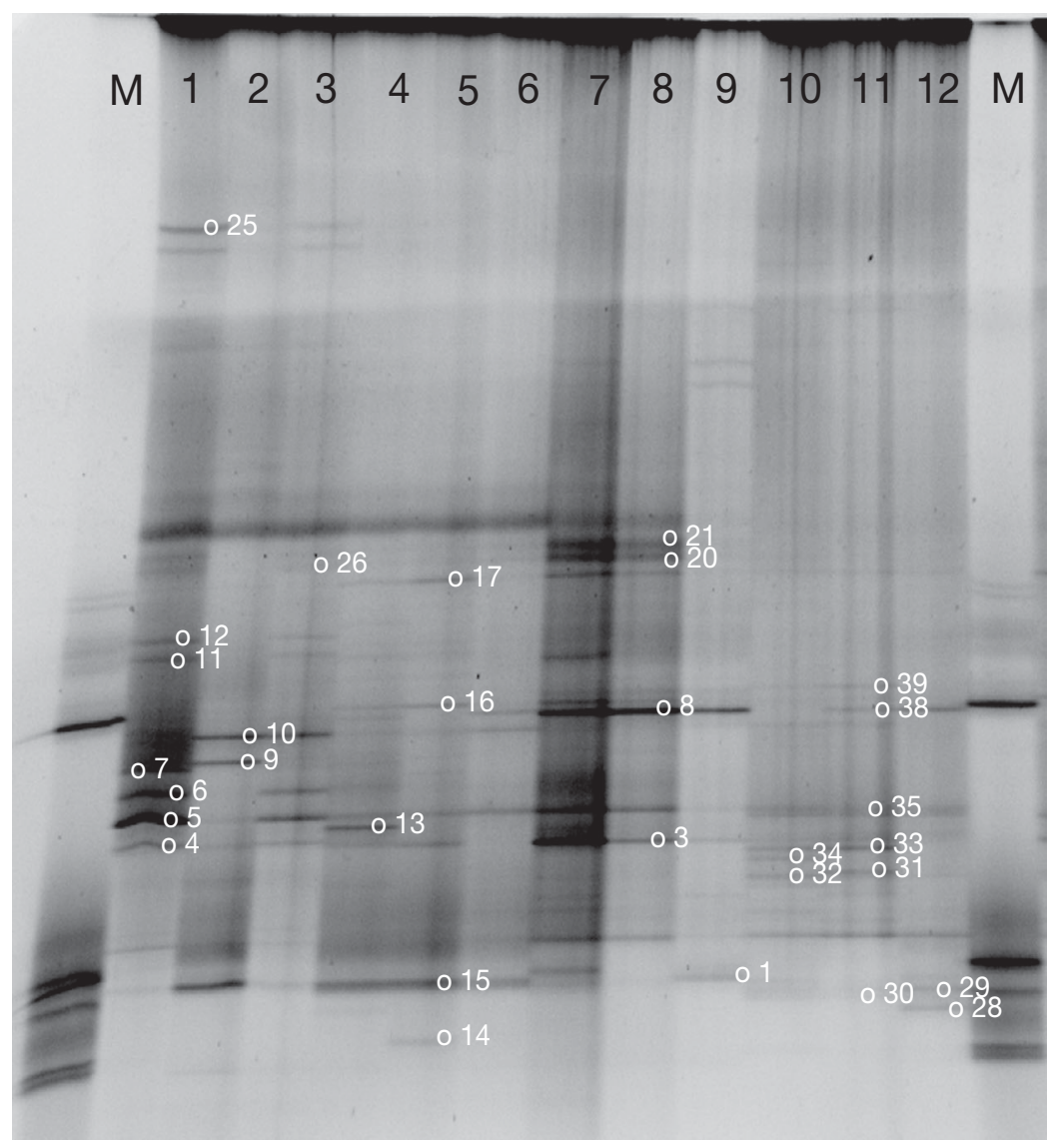

Fig. 5. Denaturing gradient electrophoretic gel of sediment samples. Lanes 1 to 3: Stn WF, 12 July 2004; Lanes 4 to 6: Stn RH, 12 July 2004; Lanes 7 to 9: Stn WI, 12 July 2004; Lanes 10 to 12: Stn WI, 13 August 2004; M: gel marker. Numbers indicate bands recovered from the gel and sequenced (see Table 3). See Fig. 1 for abbreviations

suggested that WF and RH were more similar in eukaryotic community structure than either site was to WI, a result consistent with the dendogram. The ANOSIM test for differences between samples grouped based on mean grain size was significant ( $\mathrm{p}=$ $0.01, R=0.914$ ), whereas the ANOSIM test for differences between samples grouped based on mean friction velocity was not significant ( $p=0.10, R=0.235$ ). Non-metric multi-dimensional scaling (MDS) of the DGGE presence/absence data was overlaid with mean flow velocity and mean grain size data to illustrate the differences detected by the ANOSIM tests (Fig. 7). The sites were separated clearly by grain size, but not by flow regime.

Considering only the bands identified as protists (Fig. 5, Table 3), there were variations apparent in the diatom community structure relating to both flow regime and grain size. At the 2 sites that differ in flow strength but have similar grain size (WF and $\mathrm{RH}$ ), there were 10 bands identified as diatoms. Of these, 4 appeared only at WF (weak flow, Bands 4, 7, 12, and
25) and none appeared only at RH (strong flow). Thus, $40 \%$ of the diatoms in this comparison were distributed in relation to flow. At the 2 sites that differ in grain size but have similar flow (RH and WI, July samples only), there were 7 bands identified as diatoms. Of these, 1 appeared only at RH (sandy, Band 6) and 1 appeared only at WI (silty, Band 4). Thus, $29 \%$ of the diatoms were distributed in relation to grain size. The total number of diatom sequences recovered from DGGE bands suggests that these organisms were abundant in the samples. Absence of a band does not necessarily mean the taxon was absent from the site, since it could be present at a very low abundance (see 'Discussion').

\section{Microscopical analysis of ciliate community structure}

The ciliate communities differed in several ways among the 3 stations on 12 July, 2004. Among the 3 stations, 15 ciliate species had significantly different concentrations ( $p<0.05)$, and another 5 species showed nonsignificant trends $(0.05<\mathrm{p}<0.10$; Table 4$)$. Among those with significant differences, the karyorelictids and scuticociliates were consistently more abundant at WI than at the other sites. Within other classes, the patterns of distribution varied among species. Multiple-comparisons tests between pairs of stations yielded the following results. Six species differed significantly between the 2 stations that differ in flow but have similar grain size (WF vs. RH): Aspidisca fusca, Aspidisca sp., Trithigmostoma sp., Dysteria sp., Microthorax sp., and Cohnilembus sp. Thus, of the ciliates in Table 4, $20 \%$ were distributed significantly in relation to flow. Ten species differed significantly between the 2 stations that differ in grain size but have similar flow (RH vs. WI): Remanella sp. 2, Geleia sp., Protoheterotrichida sp., A. fusca, Euplotes trisulcatus, Dysteria sp., Microthorax sp., Cohnilembus sp., Uronema sp. 1, and Scuticociliata sp. 2. Thus, $33 \%$ of the ciliates in Table 4 were distributed significantly in relation to grain size. Note that some species varied with both flow regime and grain size.

Ciliate species richness was similar at RH and WI (the 2 strong-flow sites); both values were higher than 
Table 3. DGGE (denaturing gradient gel electrophoresis) band sequences. Band numbers from the DGGE gel in Fig. 5. Highest scoring BLAST match is given in parentheses

\begin{tabular}{|c|c|c|c|c|}
\hline Band & BLAST match & $\begin{array}{l}\text { Similarity to } \\
\text { 3LAST match (\%) }\end{array}$ & $\begin{array}{l}\text { Fragment } \\
\text { length }\end{array}$ & $\begin{array}{c}\text { GenBank accession } \\
\text { number }\end{array}$ \\
\hline 1 & Polychaete (Grubeosyllis limbata) & 97 & $216 \mathrm{bp}$ & EF469161 \\
\hline 3 & Cnidarian (Junceella squamata) & 92 & $216 \mathrm{bp}$ & EF469162 \\
\hline 4 & Potential diatom (uncultured stramenopile CCI39) & 90 & $164 \mathrm{bp}$ & EF469163 \\
\hline 5 & Diatom (Detonula confervacea) & 93 & $214 \mathrm{bp}$ & EF469164 \\
\hline 6 & Diatom (Cyclotella meneghiniana) & 86 & $201 \mathrm{bp}$ & EF469165 \\
\hline 7 & Diatom (Detonula confervacea) & 91 & $190 \mathrm{bp}$ & EF469166 \\
\hline 8 & Turbellarian (Pelophila lutheri) & 57 & $184 \mathrm{bp}$ & EF469167 \\
\hline 9 & Uncertain (potential diatom) & 28 & $130 \mathrm{bp}$ & EF469168 \\
\hline 10 & Uncertain (potential diatom) & 28 & $133 \mathrm{bp}$ & EF469169 \\
\hline 11 & Diatom (Detonula confervacea) & 95 & $218 \mathrm{bp}$ & EF469170 \\
\hline 12 & Diatom (Detonula confervacea) & 93 & $214 \mathrm{bp}$ & EF469171 \\
\hline 13 & Turbellarian (Pelophila lutheri) & 68 & $215 \mathrm{bp}$ & EF469172 \\
\hline 14 & Uncertain (potential bivalve) & 25 & $212 \mathrm{bp}$ & EF469173 \\
\hline 15 & Diatom (Navicula ramosissima) & 99 & $196 \mathrm{bp}$ & EF469174 \\
\hline 16 & Synurophyte (Chlamydomyxa labyrinthuloides) & 92 & $130 \mathrm{bp}$ & EF469175 \\
\hline 17 & Prymnesiophyte (Phaeocystis globosa) & 85 & $150 \mathrm{bp}$ & EF469176 \\
\hline 20 & Diatom (Detonula confervacea) & 73 & $126 \mathrm{bp}$ & EF469177 \\
\hline 21 & Diatom (Detonula confervacea) & 93 & $220 \mathrm{bp}$ & EF469178 \\
\hline 25 & Diatom (Thalassiosira guillaridii) & 95 & $150 \mathrm{bp}$ & EF469179 \\
\hline 26 & Diatom (Detonula confervacea) & 98 & $215 \mathrm{bp}$ & EF469180 \\
\hline 28 & Copepod (Clone AT2-18) & 84 & $224 \mathrm{bp}$ & EF469181 \\
\hline 29 & Micrognathozoa (Pychnophyes greenlandicus) & 86 & $160 \mathrm{bp}$ & EF469182 \\
\hline 30 & Leech (Helobdella parranensis) & 72 & $181 \mathrm{bp}$ & EF469183 \\
\hline 31 & Nematode (chromadorid sp. JH-2004) & 71 & $127 \mathrm{bp}$ & EF469184 \\
\hline 32 & Uncertain (potential nematode) & 33 & $177 \mathrm{bp}$ & EF469185 \\
\hline 33 & Gastropod mollusc (Nerita albicilla) & 74 & $180 \mathrm{bp}$ & EF469186 \\
\hline 34 & Nematode (Viscosia viscosa) & 91 & $171 \mathrm{bp}$ & EF469187 \\
\hline 35 & Prymnesiophyte (Phaeocystis globosa) & 83 & $149 \mathrm{bp}$ & EF469188 \\
\hline 38 & Polychaete (Protoariciella uncinata) & 98 & $126 \mathrm{bp}$ & EF469189 \\
\hline 39 & Polychaete (Scolopes johnstonei) & 97 & $125 \mathrm{bp}$ & EF469190 \\
\hline
\end{tabular}

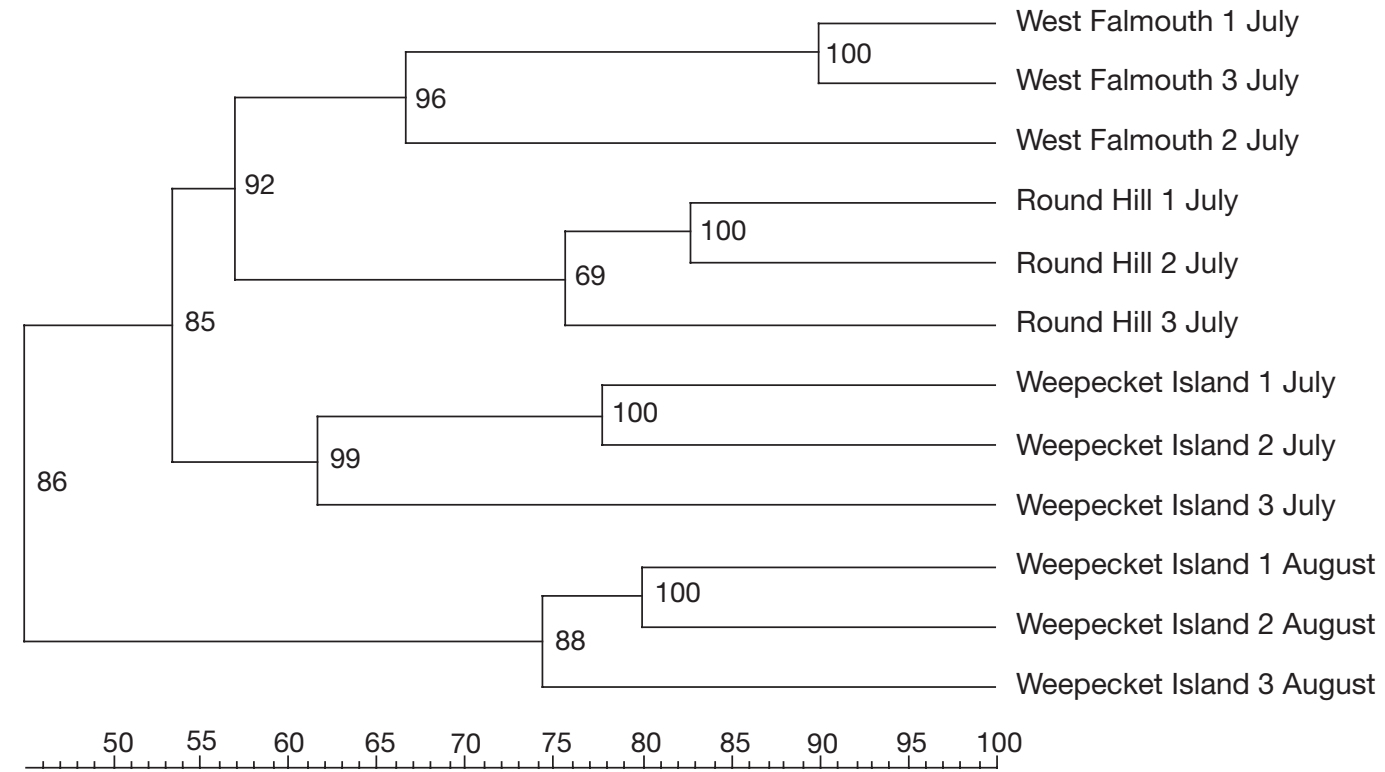

Percent similarity (shared bands)

Fig. 6. Dendogram generated from DGGE (denaturing gradient gel electrophoresis) band patterns in Fig. 5. Numbers at branch nodes are cophenetic variation values, which represent the consistency of a cluster based on dendogram-derived and matrix similarities. The percent similarity scale indicates the percentage of bands shared by samples at the branch points 
Fig. 7. MDS (multi-dimensional scaling) plot of overall microbial eukaryotic community similarity among sites based upon comparison of presence/absence of DGGE bands. The distance between samples is inversely related to their similarity (the smaller the distance, the greater the similarity). Friction velocity and grain size were superimposed on the sample points to illustrate their respective correlations with community structure. The stress value (upper left corner) is very low, indicating that the 2-dimensional plot is a reliable representation of the original data. Circles represent high mean friction velocity, and squares represent low mean friction velocity. Unfilled symbols represent silty sediment, and filled symbols represent sandy sediment

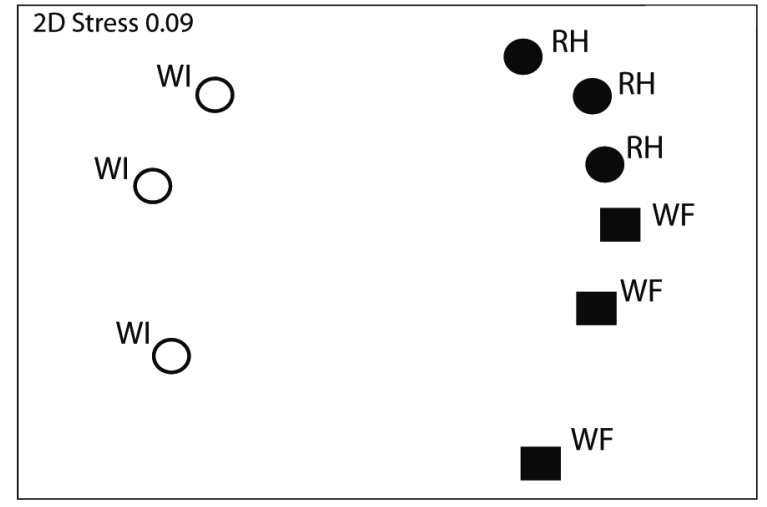

Table 4. Mean concentrations (cells $\mathrm{ml}^{-1}$ of sediment $[ \pm \mathrm{SE}], \mathrm{n}=4$ ) for the most abundant ciliate species (those with $\geq 10$ cells ml$^{-1}$ at 1 or more sites) collected on 12 July 2004 and identified microscopically using quantitative Protargol staining. Results from ANOVAs comparing all stations: ${ }^{*} \mathrm{p}<0.05$. ${ }^{\mathrm{a}} 0.05<\mathrm{p}<0.10$. Refer to 'Results; Microscopical analysis of ciliate community structure' for results of multiple-comparison tests. See Table 1 for abbreviations

\begin{tabular}{|c|c|c|c|}
\hline & WF & RH & WI \\
\hline \multicolumn{4}{|l|}{ Class Karyorelictea } \\
\hline${ }^{\mathrm{a} O r d e r}$ Protostomatida sp. & 0 & 0 & $24.2( \pm 12.3)$ \\
\hline${ }^{\mathrm{a}}$ Remanella sp. 1 & $1.4( \pm 1.4)$ & $6.4( \pm 2.4)$ & $20.6( \pm 8.2)$ \\
\hline${ }^{*}$ Remanella sp. 2 & $3.9( \pm 2.4)$ & $8.0( \pm 1.2)$ & $42.2( \pm 2.6)$ \\
\hline${ }^{*}$ Geleia sp. & 0 & $1.4( \pm 1.4)$ & $15.6( \pm 4.8)$ \\
\hline $\begin{array}{l}{ }^{*} \text { Order Protoheterotrichida sp. } \\
\text { Class Spirotrichea }\end{array}$ & 0 & $1.6( \pm 1.6)$ & $13.3( \pm 3.0)$ \\
\hline${ }^{*}$ Aspidisca fusca & $11.9( \pm 1.6)$ & 0 & $10.3( \pm 3.4)$ \\
\hline${ }^{*}$ A. steini & $20.0( \pm 3.7)$ & $28.1( \pm 6.1)$ & $56.1( \pm 9.7)$ \\
\hline *Aspidisca sp. & $1.4( \pm 1.4)$ & $16.8( \pm 5.2)$ & $6.4( \pm 2.4)$ \\
\hline Diophrys sp. & $3.9( \pm 2.4)$ & $20.0( \pm 14.1)$ & $9.2( \pm 1.2)$ \\
\hline${ }^{*}$ Euplotes trisulcatus & $11.9( \pm 3.6)$ & $1.6( \pm 1.6)$ & $15.6( \pm 3.4)$ \\
\hline Tintinnopsis sp. & $31.9( \pm 13.7)$ & $18.6( \pm 9.5)$ & $8.1( \pm 3.5)$ \\
\hline${ }^{\mathrm{a}}$ Strombidinopsis sp. & 0 & $11.2( \pm 4.6)$ & $6.7( \pm 2.5)$ \\
\hline${ }^{\mathrm{a}}$ Holosticha sp. 1 & $112.2( \pm 17.5)$ & $63.1( \pm 20.6)$ & $133.6( \pm 16.9)$ \\
\hline${ }^{\mathrm{a}}$ Holosticha sp. 2 & $31.1( \pm 6.9)$ & $12.3( \pm 1.6)$ & $15.6( \pm 5.2)$ \\
\hline Strombidium sp. & $11.9( \pm 1.6)$ & $2.5( \pm 2.5)$ & $15.3( \pm 6.0)$ \\
\hline \multicolumn{4}{|l|}{ Class Litostomatea } \\
\hline Lacrymaria sp. & $11.4( \pm 6.5)$ & 0 & $6.4( \pm 2.4)$ \\
\hline Mesodinium sp. & $7.8( \pm 1.3)$ & $3.0( \pm 1.7)$ & $12.2( \pm 5.8)$ \\
\hline \multicolumn{4}{|l|}{ Class Phyllopharyngea } \\
\hline *Atopochilodon sp. & $18.1( \pm 6.4)$ & $5.5( \pm 2.1)$ & 0 \\
\hline${ }^{*}$ Trithigmostoma sp. & $13.3( \pm 3.0)$ & $1.4( \pm 1.4)$ & 0 \\
\hline${ }^{*}$ Dysteria sp. & $20.8( \pm 3.9)$ & $1.4( \pm 1.4)$ & $25.8( \pm 6.1)$ \\
\hline \multicolumn{3}{|l|}{ Class Nassophorea } & $9.2( \pm 3.4)$ \\
\hline * Nassula sp. & 0 & $8.9( \pm 4.2)$ & $38.6( \pm 13.2)$ \\
\hline${ }^{*}$ Microthorax sp. & 0 & $11.8( \pm 2.9)$ & 0 \\
\hline $\begin{array}{l}\text { Family Microthoracidae sp. } \\
\text { Class Oligohymenophorea }\end{array}$ & $17.5( \pm 11.1)$ & $1.6( \pm 1.6)$ & $3.9( \pm 2.4)$ \\
\hline${ }^{*}$ Cohnilembus sp. & $37.5( \pm 14.8)$ & $164.3( \pm 54.6)$ & $360.3( \pm 34.1)$ \\
\hline${ }^{*}$ Uronema sp. 1 & $5.3( \pm 3.1)$ & $3.1( \pm 3.1)$ & $298.9( \pm 64.9)$ \\
\hline Uronema sp. 2 & $20.8( \pm 5.5)$ & $18.0( \pm 8.1)$ & $15.6( \pm 3.4)$ \\
\hline Subclass Scuticociliata sp. 1 & $7.5( \pm 7.5)$ & $11.4( \pm 5.1)$ & $6.4( \pm 2.4)$ \\
\hline${ }^{*}$ Subclass Scuticociliata sp. 2 & $10.3( \pm 4.1)$ & $13.9( \pm 2.3)$ & $115.6( \pm 37.5)$ \\
\hline Subclass Scuticociliata sp. 3 & $2.5( \pm 2.5)$ & $5.0( \pm 2.9)$ & $12.8( \pm 4.7)$ \\
\hline
\end{tabular}

at WF (Table 2). Species diversity was lower at WI (the silty site) than at the sandy sites (Table 2), due to the predominance of 3 scuticociliates and a Holosticha sp. at WI (Table 4). Simpson's index gave the same rank order of diversities among the sites, but we report the Shannon-Wiener index in Table 2 because it is better able to discriminate differences among samples (Magurran 1988). Community similarity was greatest between $\mathrm{RH}$ and WI (the 2 strong-flow sites), followed by WF and RH (the 2 sandy sites), and finally WF and WI (Fig. 4).

To compare with the ciliate taxa identified microscopically by Protargol staining, 52 individual ciliates were isolated by micropipette from fresh samples on 12 July 2004. Their 18S rDNA was amplified by nested PCR, and 45 generated products were run on DGGE gels. These bands were recovered, reamplified, and sequenced; 38 of the bands resulted in reliable sequences, and 27 of those gave BLAST results indicating that they were of ciliate origin. The isolates and their locations included Diophrys appendiculata $(\mathrm{RH})$, Euplotes minuta (WF), Uronychia transfuga (WF, RH), Strombidinopsis shimii (RH), Holosticha diademata (WF), Strombidium sp. SNB99-2 (RH, WI), and Trithigmostoma steini $(\mathrm{RH})$. All of these genera except Uronychia were also found in the Protargol-stained samples (Table 4), and this discrepancy could be related to the sequences available 
for comparison in the database. The remaining sequences were related to taxa other than ciliates, despite having washed the cells, and these taxa included fungi, thraustochytrids, dinoflagellates, and coccidians. Some of these might have been prey consumed by the ciliates.

\section{DISCUSSION}

\section{Flow and grain size at the sites}

In Buzzards Bay, some sites have similar regimes of tidal flow but differing grain-size distributions (e.g. RH and WI), or similar grain sizes but differing flow (e.g. WF and RH), because of complex influences of tidal and wind-driven currents and of bathymetry on sediment sorting and deposition (Moore 1963, Signell 1987, Howes \& Goehringer 1996). Although all 3 sites have similar depth, WI is within the central part of the bay that is uniformly silty and extends to some of the deepest depths, whereas WF and $\mathrm{RH}$ are closer to shore where sediments are generally coarser (Moore 1963). Nonetheless, RH and WI experience similar tidal currents, because $\mathrm{RH}$ is within a wide region of strong tidal current on the NW side of the bay and WI is on the edge of a narrow region of strong tidal current on the SE side of the bay (Moore 1963, Signell 1987). Despite similar average tidal currents, WI may remain siltier than RH, because fine grains can be harder to erode from a cohesive mud bed than from a poorly sorted bed of silt and sand (Middleton \& Southard 1984). Furthermore, wind-driven currents during episodic storms may be stronger at $\mathrm{RH}$ and WF, because WI has some protection against the predominant southerly and southwesterly winds due to the Elizabeth Islands on the SE side of the bay (Signell 1987, Howe \& Goehringer 1996).

We characterized flow regime based on mean and maximal friction velocity during spring tide, because this is expected to be the most frequently occurring and consistent period of strong flow experienced during the summer, when samples were taken. For the best comparison among sites, all data were from dates when the moon was in perigee (when it passes closest to Earth). In the summer, when the winds are weakest and storms least frequent, currents are predominantly driven by tides (Signell 1987). We thus expect the regularly occurring maximal tidal currents during spring tides to be the dominant aspect of flow forcing on the sedimentary communities. There were no storms preceding our sampling of protists. In the week preceding and including the date of each sampling (July and August, respectively), the mean hourly wind speeds were 5.3 and $7.1 \mathrm{~m} \mathrm{~s}^{-1}$, and the peak wind speeds were
9.4 and $11.3 \mathrm{~m} \mathrm{~s}^{-1}$. These values are typical of calm conditions and very close to the $15 \mathrm{yr}$ means for July through August: mean hourly speed $=6.5 \mathrm{~m} \mathrm{~s}^{-1}$, mean peak gust $=8.2 \mathrm{~m} \mathrm{~s}^{-1}$ (wind data from Buzzards Bay Meteorological Station BUZM3, National Data Buoy Center).

Although the flow and grain-size data (Figs. $2 \& 3$, Table 1) were from different years than the sampling of protistan communities, these data are representative of values measured consistently at these sites over long periods (Shimeta \& Sisson 1999, Shimeta et al. 2001, 2002, 2003, unpubl. data). At WI, 7 deployments of current meters during spring tides (not all in perigee) in the summers of $3 \mathrm{yr}$ during a $5 \mathrm{yr}$ period yielded a mean $u_{*}$ in the range of 0.70 to $0.97 \mathrm{~cm} \mathrm{~s}^{-1}$ per deployment and a mean peak $u_{*}$ in the range of 1.40 to $2.35 \mathrm{~cm} \mathrm{~s}^{-1}$ per deployment (cf. Table 1). At RH, 4 similar deployments in 2 yr during a 3 yr period yielded a mean $u_{*}$ in the range of 0.54 to $0.92 \mathrm{~cm} \mathrm{~s}^{-1}$ per deployment and a mean peak $u_{*}$ in the range of 1.20 to $1.98 \mathrm{~cm} \mathrm{~s}^{-1}$ per deployment (cf. Table 1). At WF, 2 similar deployments in 1 yr yielded a mean $u_{*}$ of 0.40 and $0.41 \mathrm{~cm} \mathrm{~s}^{-1}$ per deployment and a mean peak $u_{*}$ of 0.72 and $0.73 \mathrm{~cm} \mathrm{~s}^{-1}$ per deployment (cf. Table 1). Furthermore, the grain sizes at these sites (Fig. 3) were the same as those reported by Hough (1940) and by Moore (1963), who concluded that the sand and silt distributions in the bay have not changed since the beginning of the 20th century.

\section{DGGE analysis of eukaryotic community structure}

We used DGGE for an assessment of overall microbial eukaryotic diversity in the sediment at the 3 stations to compare the community structure between the different sediment types and flow regimes. Additionally, we were very interested in the community structure of diatoms and ciliates at these sites. We obtained many bands representing diatoms, but no bands representing ciliates. DGGE can fail to reveal relatively less abundant taxa, because the PCR reaction generally amplifies the most abundant rDNA sequences in a sample of extracted DNA (Cook et al. 2005). DGGE has been found to miss rare species of bacteria (Koizumi et al. 2003), phytoplankton (Savin et al. 2004), and metazoans (Cook et al. 2005). Besides overall cell abundance, the amount of template available for amplification from each organism also depends on the number of repeats of the target $18 \mathrm{~S}$ rDNA sequences in the genome. The number of repeats is variable among species, although most eukaryotic organisms have multiple repeat units. Despite having many copies of their ribosomal genes, ciliates may have been at lower numbers relative to the diatoms in these sediment samples. 
There were also a number of bands that were not recovered and sequenced from the gel, either because reamplification failed (missing numbers in the series) or the bands were too faint to recover. Some of these unrecoverable bands could potentially have been derived from ciliates.

Despite these issues, band presence and intensity can be a relative measure of prevalence in the natural sample. From our data, we conclude that the microbial eukaryotic population was likely dominated by diatoms at all stations in July, and that the relative intensity of diatom bands roughly reflects the cell concentrations of taxa, both at individual stations and in comparisons among stations. We caution, though, that the presence of abundant 18S rDNA in a sample does not mean that a taxon is necessarily active in metabolism or growth at the time. For example, it is possible that Thalassiosira could have sedimented from the plankton and been part of the phytodetritus. Other protists, including ciliates and nanoflagellates (Table 2) and likely amoebae, were also present at reasonable cell concentrations, but DGGE analysis of their diversities will likely require the use of PCR primers with sequences specific to these taxa in order to avoid amplifying an overwhelming amount of 18S rDNA from diatoms or metazoans.

By comparing the sedimentary chlorophyll a concentrations (Table 2) with data from these sites in previous summers when we counted pennate diatoms microscopically (Shimeta et al. 2002, 2003, unpubl. data), we estimated the concentrations of pennates in the July samples of the present study to be $1.68 \times 10^{4} \mathrm{cells} \mathrm{ml}^{-1}$ at WF, $8.73 \times 10^{3}$ cells ml ${ }^{-1}$ at $\mathrm{RH}$, and $1.19 \times 10^{4}$ cells $\mathrm{ml}^{-1}$ at WI. Common genera seen in the microscope were Navicula, Nitzschia, Pleurosigma, and Pseudonitzschia, some of which were identified from sequenced bands in this study (Table 3). These concentrations exceed those of ciliates (Table 2) by roughly an order of magnitude or more, helping to explain why many diatom bands, but no ciliate bands, were found in this study. The estimated pennate concentrations, however, are much less than the measured concentrations of nanoflagellates (Table 2), which yielded few bands (Table 3). Yet, the diatom estimates do not include centric species such as chain-forming Thalassiosira, which were seen in great abundances in samples from previous summers (J. Shimeta unpubl. obs.) and were identified from numerous bands in this study (Table 3). Therefore, it is possible that the sediment held more 18S rDNA from diatoms than from nanoflagellates.

At Station WI, the eukaryotic 18S rDNA recovered from the gel shifted from dominance by diatoms in July to dominance by metazoans in August. It is likely that metazoans increased in abundance between July and
August, but we cannot conclude that the absolute abundances of diatoms declined - only that their 18S rDNA became relatively less abundant than metazoan $18 \mathrm{~S}$ rDNA. Because of the great numbers of cells per individual metazoan, an increase of only a few metazoans in a sample could cause their 18S rDNA to dominate the PCR reaction, even if diatoms had not changed in absolute abundance. In fact, populations of sedimentary protists in Buzzards Bay typically reach their peak abundances in the late summer, after we collected the samples reported here. For example, on 29 to 31 August 2000 , concentrations of sedimentary chlorophyll $a$, bacteria, nanoflagellates, and ciliates at both $\mathrm{RH}$ and WI (Shimeta et al. 2002, 2003) were higher than in our July samples reported here by factors of 2- to 8-fold. Therefore, diatom 18S rDNA was likely abundant in August, perhaps even more than in July, despite its failure to produce recoverable bands on the gel.

\section{Community structure in relation to flow and grain size}

In the July samples, the ciliate communities (based on QPS) and diatom communities (based on DGGE) differed dramatically among the 3 stations in terms of species composition and abundances, and the ciliates differed in species richness and diversity as well. In contrast, there was generally little variation among the replicates taken at each site. Thus, the protistan community varies greatly on the scale of $10 \mathrm{~km}$ across continuous soft-sediment, unvegetated habitat of essentially constant depth (14 to $15.5 \mathrm{~m}$ ) and salinity (Moore 1963).

The distributions of ciliates and diatoms showed relationships to both flow strength and grain size. Distributions of 6 ciliate species were related to flow strength, as were both species richness and community similarity. Distributions of 10 ciliate species were related to grain size, as was total ciliate abundance. The highest similarity of the ciliate communities was between the 2 stations with similar flow, and the lowest was between the 2 stations having neither flow nor grain size in common. The dendogram of total eukaryotic diversity and the chlorophyll a measurements both showed relationships with grain size, in that the greatest similarities were between the 2 sandy sites. The analysis of presence/absence of gel bands, most of which were identified as diatoms, also revealed significant relationships to grain size, and the MDS plots suggested that grain size had a greater effect than flow strength on the overall eukaryotic community structure. Among the bands identified as diatoms, 4 out of 10 were present/absent in relation to flow strength, and 2 out of 7 were present/absent in relation to grain size. 
Populations of benthic ciliates and diatoms are known to be influenced by sedimentary grain size, although the directions of the relationships are variable. In the intertidal, ciliates generally are more abundant in medium and fine sand than in silt and mud, presumably due to the restricted pore size and permeability of the latter, which can limit cell movement as well as water drainage and oxygen penetration at low tide (Fenchel 1969, Patterson et al. 1989). For subtidal sediment we found the opposite result, i.e. an inverse relationship between grain size and ciliate abundance, as did Garstecki et al. (2000). We do not know if these differing results reflect a fundamental difference between intertidal and subtidal communities, or if our findings are specific to certain sites. Shimeta et al. $(2002,2003)$ found evidence of a surficial flocculent layer at both RH and WI, which might make WI a more suitable habitat for ciliates than expected from its small grain size. Furthermore, the higher concentrations of ciliates at WI could be explained by the higher abundances of food resources for herbivorous and predatory ciliates compared to those at the sandy sites.

The ciliate taxa with the strongest bias toward silty sediment were karyorelictids and scuticociliates. Many karyorelictids are large omnivores, common in sandy habitats (Fenchel 1968), but those we observed were small cells. Garstecki et al. (2000) also found karyorelictids to be more common in silty than sandy subtidal sediments. These species of karyorelictids might be adapted for fine sediment, and/or they might thrive at WI because of the higher concentrations of diatoms and ciliates as food resources. Scuticociliates could thrive in silty sediment because of their small cell size, and, because many of them are suspension feeders, they might benefit from aspects of the flow environment at WI (see below). Some of the differences in ciliate community structure among sites might also be explained by the differences in the diatom community structure, since herbivorous ciliates feed selectively among diatom species (Hamels et al. 2004).

Our finding of differing community structure of diatoms between silty and sandy sites is consistent with numerous studies (e.g. Colijn \& Dijkema 1981, Sabbe \& Vyverman 1991), which generally attribute the phenomenon to species-specific differences in the ability to adhere to grains, combined with differences in hydrodynamic sorting of diatom-coated sediment at sheltered (fine-grained) versus exposed (coarsegrained) sites. Among the sites we studied, hydrodynamic sorting of diatom species may be insufficient to explain the community structures, especially in the case of Stations RH and WI, where flow strength is similar even though grain size differs. Our results might nonetheless be explained by species-specific differ- ences in abilities to adhere to or migrate in grains of various size, along with potential differences in nutrient or light regimes that correlate with grain size. Our finding of an inverse relationship between chlorophyll a abundance and grain size is consistent with Colijn \& Dijkema (1981). In contrast, Cahoon et al. (1999) found a direct relationship between chlorophyll a abundance and grain size in shallow subtidal sites, and they concluded that the literature reveals no consensus on the relationship between benthic microalgal biomass and grain size.

Direct effects of flow strength on benthic ciliate and diatom communities have been researched less than influences of grain size. Shimeta et al. (2001) found in flume experiments with sediment cores from Station $\mathrm{RH}$ that the bacterivory rate of the epibenthic ciliate community was directly related to flow strength. Furthermore, the response was species-specific among bacterivorous suspension feeders (several scuticociliates and a Euplotes, the latter being inhibited in strong flow), suggesting that flow regime could affect their relative population growth rates and hence community structure. Sediment resuspension, another flowinduced process, has been shown experimentally to enhance growth rates and intensify trophic interactions throughout the sedimentary protistan community, including diatoms, flagellates, ciliates, and rhizopods (Garstecki \& Wickham 2001, Garstecki et al. 2002). Shimeta et al. $(2002,2003)$ documented periodic resuspension at Stations RH and WI, with various taxa of ciliates and diatoms displaying different thresholds of flow strength for resuspension. Thus, community structure could be affected by flow regime, as various taxa spend differing amounts of time in resuspension. Abrasion from moving sediment grains is also known to influence diatom growth rates in a species-specific fashion (Delgado et al. 1991). The processes above could explain why ciliate community similarity was greatest between the 2 strong-flow sites (RH and WI), why ciliate species richness was higher at these sites than at WF, and why the abundances of certain ciliates and diatoms differed between the strong-flow and weak-flow sites. For example, Cohnilembus sp. and perhaps Aspidisca sp. are suspension feeders, and they had their highest abundances at the 2 strong-flow sites.

There were, however, differences between the communities at the 2 strong-flow sites, e.g. the higher abundances of some scuticociliates and of total ciliates at WI. Some species had differing concentrations among all 3 sites, suggesting influences from both flow strength and grain size. An example is Cohnilembus sp., for which the optimal habitat was silty sediment in strong flow (Station WI). Furthermore, despite the fact that RH and WI have similar flow strengths, Shimeta 
et al. (2002, 2003) found that resuspension occurs more frequently at WI, which might produce greater enhancements of ciliate growth rates there.

On sandy shores, hydrodynamic disturbance has been correlated with reduced ciliate abundance and species richness (Lucchesi \& Santangelo 1997), a finding that disagrees with our results from subtidal sediments. Cell washout may be more likely on exposed sandy shores, however, than in the subtidal.

Community structure might be influenced by other factors that could vary among these sites, such as oxygen content, redox potential, nutrients, light regime, consumer species, and recruitment from the water column (Patterson et al. 1989, MacIntyre et al. 1996), some of which can also correlate with flow and/or grain size and might help to explain our results.

We characterized ciliate community structure at only 1 time (mid-July), yet it might change in a seasonal succession (Fernandez-Leborans et al. 2001). Our measurements of general abundances at RH and WI in late-August 2000 (Shimeta et al. 2002, 2003) showed, however, that, although the populations were denser, the same contrasts occur between these 2 sites in both mid- and late summer, i.e. that organic matter, chlorophyll $a$, and ciliates were more abundant at WI that at RH.

Flow regime and grain size are correlates and possibly important determinants of community structure among benthic ciliates and diatoms in Buzzards Bay, and perhaps generally in subtidal sediments. Other protists whose community structure we did not resolve (e.g. nanoflagellates and amoebae) might also be influenced by flow regime and grain size.

Acknowledgements. We thank J. Sisson, N. Trowbridge, and M. Gould for help in collecting the July samples; J. Morford, G. Yen, E. Herrle, and K. Watson for collecting the August samples; and D. Moran for help picking ciliates in the laboratory. W. Coats graciously shared his expertise in Protargol staining. Comments from 2 anonymous reviewers improved the manuscript. This work was supported by Franklin \& Marshall College and the Woods Hole Center for Oceans and Human Health (NIEHS P50 ES012742 \& NSF OCE0430724).

\section{LITERATURE CITED}

Altschul SF, Madden TL, Schaffer AA, Zhang J, Zhang Z, Miller W, Lipman DJ (1997) Gapped BLAST and PSIBLAST: a new generation of protein database search programs. Nucleic Acids Res 25:3389-3402

Cahoon LB, Nearhoof JE, Tilton CL (1999) Sediment grain size effect on benthic microalgal biomass in shallow aquatic ecosystems. Estuaries 22:735-741

Carey PG (1992) Marine interstitial ciliates. Chapman \& Hall, London

Clarke KR, Gorley RN (2006) Primer v6: user manual/tutorial. Primer-E, Plymouth
Colijn F, Dijkema KS (1981) Species composition of benthic diatoms and distribution of chlorophyll $a$ on an intertidal flat in the Dutch Wadden Sea. Mar Ecol Prog Ser 4:9-21

Cook AA, Bhadury P, Debenham NJ, Meldal BHM and 5 others (2005) Denaturing gradient gel electrophoresis (DGGE) as a tool for identification of marine nematodes. Mar Ecol Prog Ser 291:103-113

Countway PD, Gast RJ, Savai P, Caron DA (2005) Protistan diversity estimates based on 18S rDNA from seawater incubations in the western North Atlantic. J Euk Microbiol 52:95-106

Coyne KJ, Hutchins DA, Hare CE, Cary SC (2001) Assessing temporal and spatial variability in Pfiesteria piscicida distributions using molecular probing techniques. Aquat Microb Ecol 24:275-285

de Jonge VN, van Beusekom JEE (1992) Contribution of resuspended microphytobenthos to total phytoplankton in the Ems estuary and its possible role for grazers. Neth J Sea Res 30:91-105

Delgado M, De Jonge VN, Peletier H (1991) Effect of sand movement on the growth of benthic diatoms. J Exp Mar Biol Ecol 145:221-231

Epstein SS (1997a) Microbial food webs in marine sediments. I. Trophic interactions and grazing rates in two tidal flat communities. Microb Ecol 34:188-198

Epstein SS (1997b) Microbial food webs in marine sediments. II. Seasonal changes in trophic interactions in a sandy tidal flat community. Microb Ecol 34:199-209

Fenchel T (1968) The ecology of marine microbenthos. II. The food of marine benthic ciliates. Ophelia 5:73-121

Fenchel T (1969) The ecology of marine microbenthos. IV. Structure and function of the benthic ecosystem, its chemical and physical factors and the microfauna communities with special reference to the ciliated protozoa. Ophelia 6: $1-182$

Fernandez-Leborans G (2001) Relative importance of protozoan functional groups in three marine sublittoral areas. J Mar Biol Assoc UK 81:735-750

Fernandez-Leborans G, Valgañon B, Perez E (2001) Characterization of the protistan communities inhabiting the benthic area of an inner estuary. Bull Mar Sci 68:451-467

Garstecki T, Wickham SA (2001) Effects of resuspension and mixing on population dynamics and trophic interactions in a model benthic microbial food web. Aquat Microb Ecol 25:281-292

Garstecki T, Verhoeven R, Wickham SA, Arndt H (2000) Benthic-pelagic coupling: a comparison of the community structure of benthic and planktonic heterotrophic protists in shallow inlets of the southern Baltic. Freshw Biol 45: 147-167

Garstecki T, Wickham SA, Arndt H (2002) Effects of experimental sediment resuspension on a coastal planktonic microbial food web. Estuar Coast Shelf Sci 55: 751-762

Gast RJ, Dennett MR, Caron DA (2004) Characterization of protistan assemblages in the Ross Sea, Antarctica, by denaturing gradient gel electrophoresis. Appl Environ Microbiol 70:2028-2037

Hamels I, Mussche H, Sabbe K, Muylaert K, Vyverman W (2004) Evidence for constant and highly specific active food selection by benthic ciliates in mixed diatom assemblages. Limnol Oceanogr 49:58-68

Hough JL (1940) Sediments of Buzzards Bay, Massachusetts. J Sed Petrol 10:19-32

Howes BL, Goehringer DD (1996) Ecology of Buzzards Bay: an estuarine profile. Biology Report 31, National Biology Service, Washington, DC 
Koizumi Y, Kojima H, Fukui M (2003) Characterization of depth-related microbial community structure in lake sediment by denaturing gradient gel electrophoresis of amplified 16S rDNA and reversely transcribed 16S rRNA fragments. FEMS Microb Ecol 46:147-157

Lee JJ, Leedale GF, Bradbury P (2000) An illustrated guide to the protozoa, 2nd edn. Society of Protozoologists, Lawrence, KS

Lucas CH, Banham C, Holligan PM (2001) Benthic-pelagic exchange of microalgae at a tidal flat. 2. Taxonomic analysis. Mar Ecol Prog Ser 212:39-52

Lucchesi P, Santangelo G (1997) The interstitial ciliate community of a Mediterranean sandy shore under differing hydrodynamic disturbances. Ital J Zool 64:253-259

MacIntyre HL, Geider RJ, Miller DC (1996) Microphytobenthos: the ecological role of the 'secret garden' of unvegetated, shallow-water marine habitats. I. Distribution, abundance and primary production. Estuaries 19:186-201

Magurran AE (1988) Ecological diversity and its measurement. Princeton University Press, Princeton, NJ

Medlin L, Elwood HJ, Stickel S, Sogin ML (1988) The characterization of enzymatically amplified eukaryotic 16S-like rRNA-coding regions. Gene 71:491-499

Middleton GV, Southard JB (1984) Mechanics of sediment movement. Society of Economic Paleontologists and Mineralogists, Tulsa, OK

Miller DC, Geider RJ, MacIntyre HL (1996) Microphytobenthos: the ecological role of the "secret garden" of unvegetated, shallow-water marine habitats. II. Role in sediment stability and shallow-water food webs. Estuaries 19:202-212

Montagnes DJS, Lynn DH (1987) A quantitative Protargol stain (QPS) for ciliates: method description and test of its quantitative nature. Mar Microb Food Webs 2:83-93

Moore JR (1963) Bottom sediment studies, Buzzards Bay, Massachusetts. J Sed Petrol 33:511-558

Nowell ARM, Jumars PA (1984) Flow environments of aquatic benthos. Annu Rev Ecol Syst 15:303-328

Parsons TR, Maita Y, Lalli CM (1984) A manual of chemical and biological methods for seawater analysis. Pergamon Press, Oxford

Patterson DJ, Larsen J, Corliss JO (1989) The ecology of heterotrophic flagellates and ciliates living in marine sediments. Prog Protistol 3:185-277

Piceno YM, Noble PA, Lovell CR (1999) Spatial and temporal assessment of diazotroph assemblage composition in veg-

Editorial responsibility: Daniel Vaulot, Roscoff, France etated salt marsh sediments using denaturing gradient gel electrophoresis analysis. Microb Ecol 38:157-167

Sabbe K, Vyverman W (1991) Distribution of benthic diatom assemblages in the Westerschelde (Zeeland, the Netherlands). Belg J Bot 124:91-101

Savin MC, Martin JL, LeGresley M, Giewat M, Rooney-Varga $\mathrm{J}$ (2004) Plankton diversity in the Bay of Fundy as measured by morphological and molecular methods. Microb Ecol 48:51-65

Schoener TW (1970) Nonsynchronous spatial overlap of lizards in patchy habitats. Ecology 51:408-418

Shaffer GP, Sullivan MJ (1988) Water column productivity attributable to displaced benthic diatoms in well-mixed shallow estuaries. J Phycol 24:132-140

Shimeta J, Sisson JD (1999) Taxon-specific tidal resuspension of protists into the subtidal benthic boundary layer of a coastal embayment. Mar Ecol Prog Ser 177:51-62

Shimeta J, Starczak VR, Ashiru OM, Zimmer CA (2001) Influences of benthic boundary-layer flow on feeding rates of ciliates and flagellates at the sediment-water interface. Limnol Oceanogr 46:1709-1719

Shimeta J, Amos CL, Beaulieu SE, Ashiru OM (2002) Sequential resuspension of protists by accelerating tidal flow: implications for community structure in the benthic boundary layer. Limnol Oceanogr 47:1152-1164

Shimeta J, Amos CL, Beaulieu SE, Katz SL (2003) Resuspension of benthic protists at subtidal coastal sites with differing sediment composition. Mar Ecol Prog Ser 259:103-115

Signell RP (1987) Tide- and wind-forced currents in Buzzards Bay, Massachusetts. Technical Report 87-15, Woods Hole Oceanographic Institution, Woods Hole, MA

Sternberg RW (1968) Friction factors in tidal channels with differing bed roughness. Mar Geol 6:243-260

van Hannen EJ, van Agterveld MP, Gons HJ, Laanbroek HJ (1998) Revealing genetic diversity of eukaryotic microorganisms in aquatic environments by denaturing gradient gel electrophoresis. J Phycol 34:206-213

Webster G, Newberry CJ, Fry JC, Weightman AJ (2003) Assessment of bacterial community structure in the deep sub-seafloor biosphere by $16 \mathrm{~S}$ rDNA-based techniques: a cautionary tale. J Microbiol Methods 55:155-164

Weekers PHH, Gast RJ, Fuerst PA, Byers TJ (1994) Sequence variations in small-subunit ribosomal RNAs of Hartmannella vermiformis and their phylogenetic implications. Mol Biol Evol 11:684-690

Submitted: November 6, 2006; Accepted: April 30, 2007

Proofs received from author(s): June 13, 2007 